\section{Mercedes Cano Pérez}

Licenciada en Humanidades por la Universidad de Alicante y colaboradora de la Unidad de Investigación de dicha universidad Recuperaciones del Mundo Precolombino y Colonial en la Literatura Hispanoamericana de los siglos XIX y XX. Es además profesora de Lengua y Literatura españolas en el Instituto de Educación Secundaria Bellaguarda (Altea). Actualmente está realizando un trabajo de investigación más amplio sobre la figura de Lope de Aguirre en el discurso histórico y literario hispanoamericanos.
1

Arturo Uslar Pietri, La creación del Nuevo Mundo, Madrid, Mapfre, 1991.
La figura de Lope de Aguirre en Abel Posse: La fragua del personaje

MERCEDES CANO PÉREZ

\title{
LA FIGURA DE LOPE DE AGUIRRE EN ABEL POSSE: LA FRAGUA DEL PERSONAJE
}

\author{
MERCEDES CANO PÉREZ
}

Pocos personajes históricos pertenecientes al periodo de la conquista de América han adquirido esa poderosa aureola mítica que conserva todavía Lope de Aguirre. Historiadores y literatos han caído a partes iguales bajo su embrujo, a veces para admirar la hazaña del hombre y otras para abjurar los crímenes del tirano. Uslar Pietri, en su ensayo «El peregrino», cree ver la causa de esta fascinación en el profundo «sentido de lo dramático, de lo histórico y de lo mágico» ${ }^{1}$ que posee el personaje en cada uno de sus actos.

Este hidalgo nacido en Oñate (Guipúzcoa) en la segunda década del siglo XVI protagoniza una historia que no parece al principio tan distinta a las de otros que llegaron al Nuevo Mundo buscando suerte y riquezas. Sin embargo, lograría que sus pasos resonasen más que el resto, tal vez por el arrojo que puso a su empeño, por su personalidad abismal. Estuvo alrededor de treinta años en las Indias, casi siempre como uno más. Vivió el ambiente de crispación política provocado por la promulgación de las Leyes Nuevas de 1542 y se mantuvo casi siempre del lado del rey aunque con algún desliz que era perdonado al combatir al próximo insurgente. En una de estas campañas bélicas recibió un arcabuzazo en la pierna y desde entonces su cojera le acompañó como otro rasgo más de su personalidad. Era de carácter huraño y poca conversación, sólo se le conocía una debilidad, Elvira, su hija mestiza. En 1559 el marqués de Cañete encarga al gobernador Ursúa una expedición al célebre reino de El Dorado. Aguirre, un aventurero ya entrado en años, se enrola en esta empresa de dudoso éxito con unos objetivos muy distintos: aquí se inicia su plan suicida, su acceso delirante al mundo de los mitos. Una vez dentro del río Marañón consigue mediante intrigas bien calculadas matar a Ursúa y a sus allegados y proclamar como príncipe al ambicioso joven Fernando de Guzmán, que se convertirá en un títere en sus manos. A continuación, hace que los expedicionarios, ya bajo su mando, firmen un documento de desnaturalización de los reinos de España, una auténtica afrenta a la autoridad vigente. Por si esto fuera poco, escribe una airada carta a Felipe II que sella su paso por la historia: reprocha al rey su ingratitud, le recuerda sus servicios y se lamenta de haber tenido que llegar a esos extremos reivindicativos. Aguirre ya ha advertido a sus hombres que El Dorado es en realidad el reino del Perú, el único premio por el que merece la pena dejarse la vida. Así, mata o hace matar a los que le estorban, o a los que cree que lo harán. Su poder de control es absoluto y mientras viajan hasta la desembocadura del Amazonas todo pasa por sus manos. Después cruza a Isla Margarita y ahí sufre las primeras deserciones: hombres que huyen sobrepasados por la culpabilidad de sus delitos, confiando en un supuesto perdón real. Pero el tirano no se amilana, entra en Venezuela y encuentra en la localidad de Barquisimeto un final acorde con sus dimensiones: todos sus marañones (excepto uno) le abandonan y, cercado por el enemigo, mata a Elvira a puñaladas para evitarle escarnios y humillaciones propios de la hija de un traidor. Ya libre, tras haber borrado su descendencia 
en este mundo, anda solo al encuentro de los dos arcabuzazos que sus propios soldados (ahora de nuevo súbditos reales) le regalarán con gran rapidez y decisión, cualidades propias de quien teme que la víctima deje algún testimonio incómodo. Es el lunes 27 de octubre de 1561 .

Como es lógico, esta hazaña de dimensiones épicas ha sido ampliamente glosada desde sus orígenes. Partiendo de los cronistas, primitivos «cantores» de la furia de Aguirre, hasta llegar a los novelistas contemporáneos², la imagen del tirano se ha mostrado versátil y susceptible de varias interpretaciones. La que aquí nos ocupa es la que Abel Posse nos ofrece en Daimón (1978) que, según sus propias palabras, es «una novela transhistórica, metahistórica» ${ }^{3}$ que le servirá no sólo para recrear la figura terrible de Aguirre, sino que además se convierte en un intento de comprensión de la realidad y la historia americanas ${ }^{4}$. El planteamiento de la obra es la resurrección del tirano que, haciéndose acompañar de todos sus hombres, vuelve al mundo para proseguir su jornada imposible durante cinco siglos más, reanudando de nuevo «la fiesta de la guerra» 5 . Un Aguirre incestuoso y endemoniado vuelve a la vida con toda la energía maquiavélica de antaño, pero ingresará en un mundo que ya no es el suyo: llega al país de las Amazonas y le aburre su sensualidad sin malicia, ve en la Cartagena del siglo XVIII ese juego del progreso y del comercio que aniquila las antiguas jerarquías al tiempo que crea las suyas propias y visita con su séquito de marañones el anhelado Paytiti, país del oro, cuyo príncipe vive triste, como «un empleado de su propia opulencia» ${ }^{6}$. Esto corresponde con la primera parte de la novela, que se cierra con un Aguirre hastiado de sus propias andanzas y que buscará, mediante el anonimato, un camino individual hacia la felicidad.

Dicho trayecto aparece trazado en el segundo bloque en el que Lope vive al fin el amor junto a sor Ángela en un entorno ancestral, el Machu Picchu. Sin embargo esta quietud pronto abruma al hombre de acción y decide conocer la floreciente República donde descubre que todos sus marañones han prosperado: Blas Gutiérrez (antes escribano) es el prototipo del hombre ilustrado y fundador del Partido Liberal; Diego de Torres, el soldado aspirante a místico algo torpe y apocado es ahora un famoso líder estudiantil, «entregado de lleno a la mística revolucionaria» ${ }^{\prime}$; el cura Alonso de Henao ha ascendido a la categoría de Obispo y Carrión, el verdugo vocacional, se ha convertido en un coronel beligerante al que todos temen en secreto. Aguirre está fuera de juego: decide optar por un cambio radical y consuma el «erocidio matrimonial» con el necesario asesinato de su esposa. Se siente tan desolado que necesita a Huamán como guía de su proceso de liberación espiritual, tras el cual consigue entrar en «lo abierto», «deshistorizarse» ${ }^{8}$ y sentirse poco a poco americano. Viaja entonces por un continente devastado por la injusticia y la explotación y presencia finalmente el levantamiento de las fuerzas armadas a cargo de Carrión aventado, como siempre, por el amparo teológico de Monseñor Henao. En Cuzco, Aguirre se reencuentra con la Mora, un antiguo amor imposible, y vive con ella el renacer de la concupiscencia al tiempo que viene «oliendo su propia muerte»?. La joven, imbuida por el idealismo revolucionario de Torres, le propone unirse con él a su grupo de resistencia, y ahí Aguirre vuelve a sentir su «demonio», su necesidad de traición, su hambre de poder. En este momento en que el protagonista vuelve a encarrilar su imagen prototípica, a encarnar los rasgos de que la literatura y la historiografía le han dotado, muere accidentalmente, atragantado por un hueso. Pero el estigma de maldad y crueldad que representa no desaparece con él.

La visión posseana de la figura de Aguirre muestra unas peculiaridades que trataremos de analizar en este trabajo. Se trata de un personaje construido sobre unos principios caracterizadores capaces de dar unidad a una novela que en principio manifiesta una estructura poco solvente por sí misma. Lope está en cada fisura de la narración para hilvanarla con su presencia imponente: es una creación maestra. Debemos por tanto desandar el trabajo creador de Posse para atisbar cómo se presenta su personaje desde su misma concepción genesíaca. Para ello partiremos de dos vías de análisis básicas: la primera estudiará a Aguirre en relación con el contexto histórico que plantea la novela (su interacción y su forma de transitar o asumir la historia); la segunda saltará a otros textos, a un paisaje narrativo más amplio que nos permitirá ver el nacimiento del tirano desde otros personajes, desde otras voces.

\section{PERSONAJE E HISTORIA: MECANIS- MOS CONSTRUCTIVOS}

Una de las características que primero salta a la vista en Daimón es que el protagonista

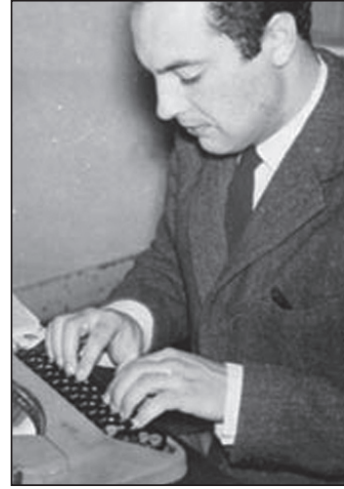

Abel Parentini Posse.

2

A este respecto, las novelas más importantes sobre el personaje son, además del Tirano Banderas (1926) de Ramón $M^{a}$ del Valle-Inclán (inspirada, al menos en parte, en el personaje), El camino de El Dorado (1947) de Arturo Uslar Pietri, La aventura equinoccial de Lope de Aguirre (1962) de Ramón J. Sénder y Lope de Aguirre, príncipe de la libertad (1979) de Miguel Otero Silva.

3

Abel Posse en Silvia Pites, «Entrevista con Abel Posse», Chasqui, 22:2 (noviembre 1993), p. 123.

4

«Voy más allá de la historia, a la metahistoria si quieres, para comprender nuestra época, para comprender nuestra raíz, nuestra ruptura, nuestra adolescencia eterna», Abel Posse en Magdalena García Pinto, "Entrevista con Abel Posse», Revista Iberoamericana (Pittsburg), LV: 146-147 (enero-junio 1989), pp. 499-500.

5

Abel Posse, Daimón, Barcelona, Debolsillo, 2003, p. 9.

6

Ibid., p. 137.

7

Ibid., p. 260

8

lbid., p. 226.

9

Ibid., p. 280.
La figura de Lope de Aguirre en Abel Posse: La fragua del personaje

MERCEDES CANO PÉREZ 


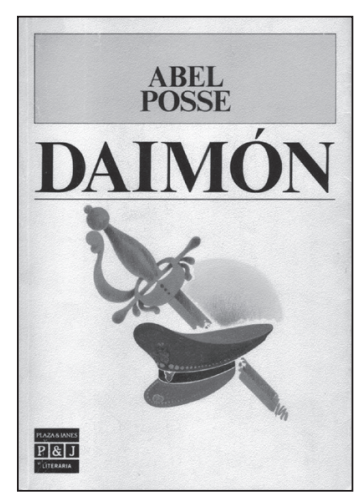

Portada de Daimón.

10

Véase Seymour Menton, La Nueva Novela Histórica de la América Latina 1979-1992, México, FCE, 1993, p. 43.

11

Daimón, p. 102.

12

Ibid., p. 108.

13

Id.

14

Teodosio Fernández en Luis Sáinz De Medrano (coord), La Semana de Autor sobre Abel Posse, Madrid, Ediciones de Cultura Hispánica, 1997, p. 32. Este estudioso evidencia la presencia de este punto de vista en obras como $E l$ general en su laberinto (1989) de Gabriel García Márquez, La visita en el tiempo (1990) de Uslar Pietri y El largo atardecer del caminante (1992) del propio Abel Posse.

15

$M^{a}$ Cristina Pons en Memorias del olvido (México, S XXI, 1996) advierte que "el género de la novela histórica no sólo es una manera de (re)escribir, sino que también implica una manera de leer. Se podría decir que esta manera de leer entraña un proceso de «percepción dirigida» (Jauss) determinado por el contrato de lectura que el género establece a partir de sus rasgos convencionales y modos de tratar y percibir la realidad histórica. Este contrato de lectura genera en el lector una determinada predisposición frente al texto y provee las pautas, o instrucciones (como las llama Eco), que han de regular el proceso de lectura en la producción de sentido» (p. 29). En el caso que nos ocupa, la novela reformula desde su misma lectura las pautas para su interpretación.

La figura de Lope de Aguirre en Abel Posse: La fragua del personaje

MERCEDES CANO PÉREZ se enclava continuamente en un contexto dinámico, fulgurante, proteico: el suelo que pisa Aguirre siempre se mueve bajo sus pies. En la novela histórica tradicional, el personaje brota de la historia y la habita, siendo un producto de ella: el autor rescata a la figura elegida y detiene el devenir temporal para enfocarla mejor. En este sentido es como si la historia sustentase y fijase con su fuerza inmanente el protagonismo del hombre frente al devenir en el que está inmerso, que es por naturaleza destructor de todo lo humano. En la obra de Posse ocurre lo contrario: es la historia la que habita en el personaje, el cual se caracteriza precisamente por su dinamismo temporal y por su persistencia frente a todo lo voluble. Aguirre fagocita el contexto a fuerza de caminar sobre él, de consumirlo, de integrarlo. Como novela histórica, el procedimiento se invierte y se produce el impacto interpretativo: el tiempo pasa con gran celeridad y cinco siglos no son nada para un hombre que deambula con andares despistados por el florecimiento del comercio colonial, el afrancesamiento aletargado de la república y el auge de las dictaduras militares. Para conseguir esta volatilidad histórica, este contexto en movimiento, la trama novelesca se vertebra a partir del peregrinaje ucrónico de Lope. Aguirre se ha convertido en un vagabundo vocacional $y$, si su itinerancia espacial nos recuerda a la del personaje real, histórico (pensemos en ese viaje hacia la nada en aguas amazónicas), es también capaz de sorprendernos con un nuevo tipo de peregrinaje, el temporal, que borra las fronteras más básicas de lo racional y lo posible y se propone un trayecto delirante por la historia de América. En Daimón, lo histórico, que está hecho de tiempo inasible, inabarcable, aparece asimilado a lo espacial, que es una entidad transitable y al alcance del hombre: Aguirre circula por el tiempo.

Este planteamiento discursivo presupone ya de por sí un marco textual de dislates temporales. La presencia de la anacronía pasa de ser un recurso propio de la Nueva Novela Histórica (como ya destacó Seymour Menton $^{10}$ ) a convertirse en un procedimiento estructural en la concepción del personaje que contribuye a su sentido y definición. El espíritu anacrónico de Aguirre se traduce en una versátil marginalidad, capaz de redefinirse y reubicarse en cada momento y lugar. Por ejemplo, en Cartagena descubre que los tiempos han cambiado y al conocer las nuevas y poderosísimas armas de fuego "comprendió que el poder de los emperadores europeos era ahora terrible: habían sabido incorporar la ciencia a su maldad de siempre» ${ }^{11}$. Allí siente su derrota con «cierta vergüenza, como de provinciano fracasado en fiesta mayor» ${ }^{12}$. El personaje real era un conquistador en una época en que los conquistadores han perdido independencia y poder; de ahí nace su reivindicación, su disidencia. De modo análogo, el Aguirre de Posse siempre se encuentra fuera de lugar, desubicado, y su manera de vivir la nostalgia adquiere la forma de un encuentro paulatino con lo americano, de identificación con el continente:

Por primera vez en sus sucesivas vidas se sintió americano. Al menos con el rencor del americano y ese cierto orgullo vegetal y paisajístico que con el tiempo sería confundido con mero folklorismo ${ }^{13}$.

En cierta manera, esa visión del protagonista histórico en un momento crepuscular, de decaimiento y crisis vital, nos recuerda la definición que Teodosio Fernández esbozó para una nueva óptica narrativa en la literatura hispanoamericana, adoptada desde finales de los ochenta y caracterizada por contemplar al personaje "desde un ángulo personal, privado, menor, marcado por el desengaño ante empresas azarosas e inútiles coronadas por el fracaso» ${ }^{14}$. En este caso la configuración espiritual de este modelo protagónico se adelantaría hasta 1978, fecha de publicación de Daimón.

Por otro lado, se puede afirmar que Posse juega con la idea de la ruptura del pacto de lectura establecido de antemano. Entendemos por pacto de lectura el conjunto de expectativas que el lector se crea al acercarse a una obra y que afecta especialmente a las líneas interpretativas y a la verosimilitud del relato ${ }^{15}$. Al hablar de Nueva Novela Histórica, categoría a la que pertenece Daimón, estas perspectivas semánticas se amplían notablemente y la tergiversación de la base referencial es más común, aunque veremos que en este caso es total. Aguirre es un personaje de los que se suele decir que vehiculan ideas, principios o mensajes bien sean positivos o negativos: el Aguirre victimario, rebelde, abominable ha sido el más socorrido, quedando el Aguirre idealista para unos pocos nostálgicos. De forma sorprendente, en Posse nos encontramos con un Lope sin programa ni discurso, cuya «resurrección» le ha hecho surgir de la nada perdiendo paulatinamente su codificación histórica originaria. Lope se reinterpreta desde el presente obviando su carga pretérita: ya 
no es el que domina a sus hombres mediante el terror y busca en sus crímenes una reivindicación honesta, pero tampoco es un idealista, un luchador, un revolucionario ${ }^{16}$. Aguirre es simplemente una creación literaria profundamente descastada que, en su continuo caminar, va liberándose progresivamente de su carga semántica previa y obliga al lector a un ejercicio continuo de reconsideración hermenéutica. Es un personaje al que se dota en el relato de una profunda libertad, que juega continuamente a que busquemos su referente histórico para desmentirlo.

Posse ha indicado en alguna ocasión que Aguirre simbolizaba «la barbarie maravillosa de España, la barbarie que termina con una aventura desopilante y genial, aunque monstruosa» y que en este sentido él se proponía «rehabilitar» ${ }^{17}$ dicha barbarie. Quizá la restitución del tirano sea esta visión profundamente personal de un personaje que ya no predica nada, que carece de mensaje, que está condenado a ver un ciclo concluido del que ya no forma parte. Tampoco funciona en su proyecto redentor el espejismo de la salvación romántica: intenta «hacerse» americano, pero cae sobre él la losa de la predeterminación histórica. La embriaguez de poder y traición le llevan a querer engañar a la Mora y apartar del camino al nuevo héroe, el «santurrón Diego de Torres» ${ }^{18}$. A priori, Lope se nos presenta como símbolo del poder, dentro de la categoría de los «daimones», término que aparece definido en Los perros del paraíso como «ángeles insolentes» que «moran al margen del código cristiano» y por ello «no necesitan salvarse»; su único objetivo es cumplir «las leyes de su misión» ${ }^{19}$. Aguirre es pues un daimón, pero inocuo, fuera de su ámbito originario y reemplazado por una mutación más talentosa, más contemporánea, que es la de la tiranía organizada, hecha sistema. Sólo camina para invalidar su versión oficial, sin tener una nueva que ofrecer. Ya ni siquiera puede ser la imagen de la barbarie y la violencia porque incluso su maldad ha quedado obsoleta: es un espectro en todos los sentidos, es «el fantasma de su fantasma» ${ }^{20}$.

De la conjunción entre un contexto eternamente en movimiento y la configuración de un prototipo sin ideario, surge el tercer mecanismo constructivo que estudiaremos en Daimón: el voyeurismo como forma de interacción entre mundo y personaje. Como ya dijimos, en Aguirre todos vieron una codificación de algo, un símbolo. Posse, en este punto, procura no ver nada y deja que sea su personaje el que vea, ejerciendo el valioso oficio de voyeur. De hecho, toda la novela es una exuberante recreación de esta mirada asombrada.

El autor no necesita explicar el demonismo ni la crueldad proverbial de este ser ferino porque lo convierte directamente en una constante histórica de maldad, barbarie y poder, es decir, un daimón. Es significativo en este sentido que la novela reciba su título de esta denominación abstracta, genérica, y no de su encarnación concreta en el texto que sería, en principio, Aguirre. Decimos en principio porque si el tirano es un daimón en el siglo XVI, no lo será en los posteriores: asistimos entonces a su lucha por la supervivencia frente a sus homónimos, al salvajismo de la ley de selección más darwinista, una batalla perdida de antemano. En la propia novela aparece una cita referida al mundo animal que explica en forma de parábola este proceso que describimos:

Los jabalíes también crean jerarquías y jefes militares. Vive este jefe una vida profundamente antinatural, se hace proclive al abuso y la prepotencia creando serios desórdenes entre el hembraje. Mientras es joven parece imitar al tigre, perdidas las fuerzas transfórmase de jabalí en rencoroso cerdo que los jóvenes despedazan en un sacrificio de renovación ${ }^{21}$.

No hace falta que imaginemos quién es ese ex-jabalí desplazado: Aguirre se convierte en una reliquia andante. De ahí que su función queda circunscrita únicamente a la contemplación impertérrita, exenta de predicamento. Lope es un hombre aturdido en un mundo polimórfico que le excluye. Descubrirá que en esa nueva era «habían triunfado los putillos administrativos sobre los guerreros ${ }^{22}$, pero, como carece de la facultad del autoanálisis, no logrará darse cuenta de que él mismo «tenía un sentido arcaico y aristocrático del poder, olvidándose de que todo poder, incluso el suyo, siempre nace de la infamia, de la usurpación» ${ }^{23}$. Posse omite toda limitación significativa en la creación de Aguirre al convertirlo en un espíritu errante, antaño paradigma histórico y ahora sólo voyeur caduco de sus
16

Así lo vieron, entre otros, Simón Bolívar, el historiador Segundo de Ispizua o el novelista Miguel Otero Silva.

17

Abel Posse en Sáinz de Medrano (coord.), La Semana de Autor sobre Abel Posse, op. cit., p. 77.

18

Daimón, p. 283.

19

Abel Posse, Los perros del paraí so, Barcelona, Debolsillo, 2003, p. 83

20

Daimón, p. 212.

21

Ibid., p. 145.

22 Ibid., p. 113.

23

lbid., p. 269

La figura de Lope de Aguirre en Abel Posse: La fragua del personaje

MERCEDES CANO PÉREZ 


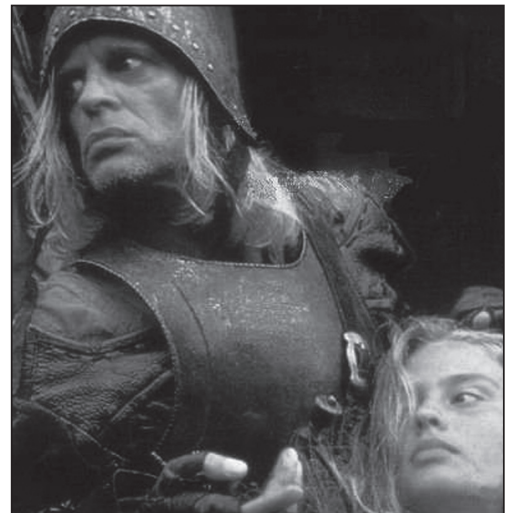

Klaus Kinski interpretando a Lope de Aguirre en Aguirre, la cólera de Dios.

24

Véase Elena Mampel González y Neus Escandell Tur (eds.), Lo pe de Aguirre. Crónicas 1559-

1561, Barcelona, Publicaciones y Ediciones de la Universidad de Barcelona, Editorial $7 \mathrm{1} / 2$, 1981

25

Hablamos por ejemplo de El camino de El Dorado (1947) de Uslar Pietri o La aventura equinoccial de Lope de Aguirre (1968) de Ramón J. Sénder.

26

Posse en $M^{a}$ Beatriz Aracil Varón, Abel Posse: de la crónica al mito de América, Universidad de Alicante (Cuadernos de América sin nombre, no 9), 2004 , p. 211 .

27

Posse en La Semana de Autor, op. cit., p. 83.

28

J. M. Caballero Bonald en ibid., p. 28.

29

Vázquez-Almesto en Mampel, op. cit., p. 270

30

Daimón, p. 44

31

Ibid., p. 46.
La figura de Lope de Aguirre en Abel Posse: La fragua del personaje

MERCEDES CANO PÉREZ herederos en la atrocidad: los modernos tiranos del caudillismo militar, es decir, Carrión y sus esbirros. Así, el personaje no necesita coartada en su itinerancia americana y puede opinar y admirar, fundirse en lo que ve aunque sin entender nada, ni siquiera a sí mismo. La vuelta del Viejo tiene un valor testimonial: cuando se plantee de nuevo la acción violenta y reconquistar el primer plano de los acontecimientos (reingresar en la historia), se cierra su círculo. Su funcionalidad en la novela es como espectador, no como agente: quizá su condena (y al tiempo su salvación) sea presenciar su propia condición de desplazado, de marginal.

\section{EL NACIMIENTO DEL PERSONAJE DESDE LA INTERTEXTUALIDAD}

Hay varias referencias textuales y literarias mineralizadas en la constitución del personaje complejo que protagoniza Daimón. Dar cuenta de todas ellas es tarea imposible para un trabajo de pretensiones tan modestas como el presente. Pero sí podemos atisbar algunas presencias esenciales que orquestan los principios básicos de este Aguirre novelesco, que solapa en su andadura, mostrándolo sólo a veces, un universo intertextual abarcador y polifónico que se ensancha a medida que es catalogado. Subyace un juego de latencias en la obra, un torrente de voces que quieren significar y salir de los oropeles.

Nos centraremos en dos núcleos textuales fundamentales por su trascendencia: el primero de ellos sería el mundo de las crónicas que narraron los acontecimientos históricos de la rebelión de Aguirre; el segundo entroncaría con el viraje de Abel Posse hacia unos modelos literarios más genuinamente americanos $\mathrm{y}$, en particular, argentinos.

Se conservan seis testimonios documentales que narran el episodio homicida urdido por Aguirre ${ }^{24}$. Cuatro de ellos son obra de antiguos compañeros del tirano, marañones, que se pasaron al bando real al constatar que la rebelión se precipitaba hacia el fracaso; son Gonzalo de Zúniga, Pedro de Monguía, Custodio Hernández y Pedrarias de Almesto que reelabora y modifica un manuscrito previo de Francisco Vázquez. De las otras dos crónicas, una es anónima y la última, la más amplia, es obra del historiador Toribio de Ortiguera. Los cuatro primeros cronistas escribieron sus versiones para justificarse ante el poder real y, así, pintan el demonio de Aguirre con colores vivos y cegadores, un ser protervo que los lleva a todos a la perdición.

Daimón no es una novela que parta fielmente de las crónicas para elaborar su mundo propio, su logos; o al menos no las sigue del mismo modo en que otras obras basadas en el mismo personaje histórico lo han hecho ${ }^{25}$. Posse utiliza todo este material con total libertad creativa, pero aún así es imposible no ver en el magma poético que es la novela múltiples referencias, transformadas o solapadas, a la voz de los cronistas. Hechos, personajes y situaciones aparecen en ocasiones desrealizados por el trabajo literario, pero siempre subyacentes en el texto. El propio Posse reconoce que «en ese viaje espiritual y admirativo hacia la América ancestral, necesité leer y releer las Crónicas» ${ }^{26}$. Este proyecto de reelaboración ha sido efectuado por el autor argentino siguiendo un principio que él mismo denomina «fraguar imaginativamente la crónica» ${ }^{27}$ y, para ello, no parte de la mera traslación de acontecimientos históricos al plano novelesco, sino que alambica ese discurso con una lógica delirante, similar a la de los sueños. Este onírico proceso de montaje ha sido definido con gran acierto por José Manuel Caballero Bonald cuando afirma que «lo que se ha propuesto Abel Posse, antes que nada, es desarticular el engranaje de algunas viejas crónicas para volverlo a montar según unas sorprendentes instrucciones de uso» ${ }^{28}$. Intentaremos ver en este punto qué elementos del tirano histórico prevalecen en el posseano, y qué metamorfosis ha producido el filtro novelesco.

Uno de los rasgos que los cronistas reiteran de Aguirre es su insomnio vigilante. Dicen que «fué gran sufridor de trabajos, especialmente del sueño, que en todo el tiempo de su tiranía, pocas veces le vieron dormir, si no era algún rato de día, que siempre le hallaban velando» ${ }^{29}$. Esta actitud controladora se reitera y magnifica en Daimón, donde Aguirre aprovecha el sopor tropical para luchar contra «los activistas nocturnales que existen en todo grupo humano» ${ }^{30} \mathrm{y}$ practicar la desconfianza, su vicio predilecto. Además, «cuando los hombres se disponen a iniciar los trabajos del día se echa en el camastro a dormitar, con un ojo entreabierto» ${ }^{31}$. En la novela esta cualidad de insomne omnipresencia se magnífica de tal modo que ni siquiera un hecho tan incuestionable como la muerte le afecta: no duerme, no descansa y, en conclusión, tampoco mue- 
re. Ello le permite ejercer esa condición de voyeur que apuntábamos: lo ve todo porque debe verlo todo.

Sin lugar a dudas, el elemento caracterizador más reiterado en los cronistas es el demonismo del tirano. Al parecer, era imposible urdir cualquier plan para rebelarse contra sus imposiciones, ya que "por ninguna vía pudieron matarle ni alzarse por el Rey nuestro señor, porque las veces que se intentó, paresce quel demonio se lo decía, parece traer familiar (...) y lo sabía luego»32. Es tal su vocación infernal que habla con "palabras luciferinas» ${ }^{33}$ y que entre sus soldados prefería sin duda a los hombres que «si fuese menester, jugasen con el demonio el alma á los dados» ${ }^{34}$. En Daimón, la presencia de lo satánico aparece manifiesta desde el principio; de hecho el personaje convive con esta voz interior y «en su mayor intimidad, casi sin palabras, sentía que las mejores cosas de su vida habían venido del lado del Bajísimo» ${ }^{35}$. Cuando reflexiona sobre su propia naturaleza no puede dejar de lado esta característica inherente, la compañía que siempre le asesora: «¿Qué sería un hombre como yo sin el Demonio? ¡Nada! ¡Una nulidad, un cagatinta armado! $¡$ Hay hombres que son un ángel, como San Francisco, y otros que son su demonio... pero son» ${ }^{36}$. Hay una irrevocable razón para la presencia de la Voz en Aguirre y ni siquiera el patético exorcismo al que el padre Henao le somete al principio de la novela consigue separarlo de lo que es su especificidad histórica y personal.

Otra idea fundamental rescatada de las crónicas es la relación del personaje con la escritura, una cualidad que dejó constancia documental de su reivindicación personal. Uno de los momentos más estremecedores de la rebelión de Aguirre es esa carta llena de desencanto que remitió a Felipe II $^{37}$ donde se define a sí mismo como «rebelde hasta la muerte» ${ }^{38}$. En Daimón queda mucho de aquella manía epistolar: en su rodeo metahistórico, Aguirre escribirá dos misivas más a su odiada majestad en las que juega intertextualmente con la carta originaria y proclama a los cuatro vientos el inicio de «la jornada de América» ${ }^{39}$. Lo más irónico es que este personaje, que consiguió la inmortalidad histórica gracias a un hecho escritural, sea considerado en la novela como un «semianalfabeto» que «si bien no entendía la letra exacta, con los siglos (...) había aprendido a comprender el sentido general de los signos» ${ }^{40}$. Dentro del mismo grupo de coincidencias y guiños podemos considerar su relación de amor y odio con
Blas Gutiérrez, el Escribano (más adelante el intelectual liberal), encargado de transcribir su aventura épica y al que hará torturar para arrepentirse al poco y confesarle: "i...no sé qué haría sin ti! ¡Eres el único que va comprendiendo algo de las cosas...! ! ${ }^{41}$.

La lectura de las crónicas evidencia una peculiar relación de Aguirre con las mujeres. No sólo no cae hechizado como todos ante doña Inés, la amante de Ursúa y «la mas linda dama que en el Peru quedaua a dicho de quantos la conocieron ${ }^{42}$ sino que además ordena matarla y la culpa del desencadenamiento de la violencia entre los soldados. En Daimón Aguirre es un «erotómano tímido pero tenaz» ${ }^{43}$, un romanticón apasionado que arrastra hasta la ultratumba un amor nunca confesado hacia esta perturbadora mujer, de la que se convierte en una especie de pretendiente eterno cuyas «misivas de amor eran cadáveres apuñaleados pero doña Inés no aceptaba descender a ese lenguaje de horror, de ensangrentados significantes» ${ }^{44}$. De nuevo según los cronistas, el tirano manifestó reiteradamente «que habia de matar á todas las malas mujeres de su cuerpo, porque estas eran causa de grandes males y escándalos en el mundo» ${ }^{45}$ y, por otro lado, «las que eran honradas mujeres las honraba mucho» ${ }^{46}$. El Aguirre posseano es una marioneta de la femme fatale que es la Mora, primero prostituta y luego activista revolucionaria a la que él se sabe, pese a todo, predestinado ya que, como suele ocurrir, «es terrible la pasión de los hombres difíciles por las mujeres fáciles» ${ }^{47}$. La buscará incansable en las tabernas y borracherías de las ciudades sin alma, mientras escucha por primera vez el tango $y$ siente que este acercamiento musical con lo americano es «un lazo para siempre» ${ }^{48}$. En las crónicas el cojo Aguirre se hace acompañar a todas partes con su hija, «que era mestiza, que trujo del Pirú, á la qual queria y tenia en mucho» ${ }^{49}$. Casi todos los testimonios confirman este amor incondicional del soldado por su descendiente, «a quien quería mas que a su vida» ${ }^{50}$, pero en Daimón este respeto casi sagrado por la niña Elvira se convierte en un incesto perpetuado, consentido y fructífero. En conclusión, en el trasvase del personaje histórico al novelesco hay una prolongación de significantes evidente: la castidad tenebrosa del Aguirre real se rebela y desata en Daimón. Parece que se establece un puente entre los textos históricos y la novela, y donde aquéllos ocultan, ésta explicita: Lope mata a la inalcanzable Inés porque no puede tener-
32 Gonzalo de Zúñiga en Mampel, op. cit., p. 14

33 Toribio de Ortiguera en ibid., p. 102.

34 Vázquez-Almesto en ibid., p. 269. 35 Daimón, p. 49. 36 Ibid., p. 50

37

Véase Vázquez-Almesto en Mampel, op. cit., pp. 254-259.

38 lbid., p. 259.

39

Daimón, p. 26.

40

Ibid., p. 179.

41 Ibid., p. 94

42 Custodio Hernández en Mampel, op. cit., p. 197.

43

Daimón, p. 9.

44

Ibid., p. 44.

45 Vázquez-Almesto en Mampel, op. cit., p. 238

46 Gonzalo de Zúñiga en Ibid. p. 21.

47

Daimón, p. 110.

48 Ibid., p. 245.

49 Gonzalo de Zúñiga en Mampel, op. cit., p.21.

50

Crónica anónima en ibid., p. 277.

La figura de Lope de Aguirre en Abel Posse: La fragua del personaje

MERCEDES CANO PÉREZ 
«Sólo la había podido echar a tierra mediante las estocadas que le dieron sus esbirros, Carrión y Antón Llamoso, y sólo entonces ella comprendió, cuando agonizaba violentada, el salvaje amor o deseo que se escondía detrás de aquellas muertes, incluida la de ella», Daimón, pp 44-45.

52

Gonzalo de Zúñiga en Mampel, op. cit., p. 19.

53

Vázquez-Almesto en ibid., pp. 241-242. Aguirre escribe esta carta para exponerle su situación y rogarle por la vida de su compañero marañón Pedro de Monguía que, sin que él lo sepa todavía, acaba de traicionarlo.

54

Ibid., p. 242.

55

Ibid., p. 269.

56

lbid., p. 258.

57

Ibid., p. 219.

58

Daimón, p. 142.

59

Ibid., p. 108

60

Ibid., p. 286.

61

Abel Posse en Magdalena García Pinto, op. cit., p. 498.

La figura de Lope de Aguirre en Abel Posse: La fragua del personaje

MERCEDES CANO PÉREZ la ${ }^{51}$, quiere tanto a su hija que llega incluso a amarla como mujer y pronuncia pequeñas diatribas cotidianas contra las malas mujeres porque le fascinan y es incapaz de controlarlas como controla todo lo demás. Daimón se convierte también en una crónica amorosa bastante extensa que completa el cuaderno de bitácora del protagonista en su periplo, que es a la vez un trayecto por la historia y por el amor.

Uno de los motivos más desazonantes en la personalidad del hidalgo de Oñate fue la conciencia que de su propia muerte (y de la de todos) mantuvo en su viaje destructivo. En efecto, parece elegir este destino más que asumirlo:

Tenía de costumbre, en matando alguno, decir á los demás: «Ea, caballeros, macheteros delante», dando á entender que á los que mataba enviaba delante á abrir y machetear el camino por donde él y los demás habían de ir tarde ó temprano ${ }^{52}$.

En la carta que escribe al Provincial Montesinos $^{53}$, le advierte al padre que «los que vinieren contra nosotros, hagan cuenta que vienen á pelear con los espíritus de los hombres muertos» ${ }^{54}$. Él mismo sabía (según sus soldados afirmaron) «que su ánima no se podia salvar; y que estando él vivo, ya sabía que ardía en los infiernos» ${ }^{55}$ y así le dejó constancia al rey en su carta de que no había salida para él ni para ninguno de sus hombres, ya que «no hay en el río otra cosa, que desesperar» ${ }^{56}$. Hay en la figura de Lope de Aguirre toda una poética de la muerte que se potencia sin desvirtuarse en Daimón. El caudillo vuelve a la vida con sus hombres, pero sigue siendo una presencia fantasmal en un mundo ambiguo que lo ignora. No hay un salto narrativo desde las crónicas a la novela sino que todo adquiere los visos de una prolongación, fantástica e irreverente, pero donde se materializan esas premoniciones macabras que poblaban el lenguaje de las crónicas.

El último anzuelo que lanzaremos a los testimonios de la rebelión de los marañones será el que denominaremos el tópico de la traición. El tirano estampó su firma en una carta colectiva en que los marañones justificaban, entre otros escarceos, el asesinato de Ursúa. Pero no se conformó con plasmar su nombre, ya de por sí portador de un designio trágico, sino que lo completó con el apelativo de «traidor» ${ }^{57}$, término que alcanzaba, como es lógico, a todos los firmantes. Así empezó a dominarlos para que se desvincularan de su lejana majestad española: les marcó con la enseña de la deslealtad y los trató de condenar junto con su alma. Sin embargo su plan se desmoronará cuando sus hombres se aferren a las cédulas reales de perdón repartidas por doquier ya en el momento final de su odisea. Fue traicionado por todos excepto por el siniestro Antón Llamoso.

Si Daimón es el desquite, el retorno del personaje, la traición aparecerá pero devuelta a sus primeros ejecutores: Aguirre se venga de sus subordinados que, en la vida terrenal, le jugaron la mala pasada de dejarle solo y convertirse en sus iracundos arcabuceros. Cuando llega a Paytiti la delegación del nuevo Inca pidiéndole al tirano colaboración, éste escucha al Bajísimo y entrega a sus hombres: «el Viejo sentía algo verdaderamente grande, excepcional: los había vendido a todos de pies y manos» ${ }^{58}$. Tras la treta liberadora se siente feliz y consciente de que «un traidor debe traicionar todo, incluso sus cómplices, sus muertos, su costumbre» y concibe la existencia «como sucesión de traiciones que nos liberan de los efectos de la anterior ${ }^{59}$. El Aguirre traidor de los cronistas traslada aquî su felonía a otros ámbitos (más privados, más personales y vengativos) sin variar un ápice su voracidad. De hecho, el final de la novela es una nueva traición, esta vez a la Mora y a sí mismo, a ese nuevo Aguirre «sudamericanizado» pero habitado todavía por un incansable y «furioso daimón» ${ }^{60}$ que no puede morir con él, que seguirá su andadura circular por la historia.

El segundo universo intertextual implicado en la novela conduce a un ámbito de análisis bien distinto: el de los modelos literarios argentinos que afloran en el Aguirre de Daimón. Las primeras novelas de Posse, Los bogavantes (1970) y La boca del tigre (1971), se encuentran muy próximas tanto en la temática como en el lenguaje a un espíritu profundamente europeísta, influenciado en buena manera por el cosmopolitismo bonaerense. Según reconoce el mismo autor: «...yo no estaba dentro de mi voz (...). Yo escribía fuera de mí, como un escritor porteño» ${ }^{61}$. Tras estas obras se abre un silencio creativo que se rompe en 1978 con Daimón, trabajo que inaugura un nuevo estilo, una inédita mirada hacia la historia de América y su literatura. Esta novela inauguraría la llamada «Trilogía del Descubrimiento», continuada con Los perros del paraíso (1983) y todavía inconclusa con la reiterada promesa, cada vez 
más cervantina, de Los heraldos negros. Este proceso de reconocimiento, de búsqueda de los orígenes, es explicado de la siguiente manera por Posse:

... mis primeras novelas están relacionadas con el universo verbal de Buenos Aires, pero yo también descubrí América (...). Sufro, pues, una transformación: yo era un escritor netamente argentino, al modo de como eran los escritores argentinos de la época: porteños, europeizantes, exclusivistas, y tuve una revelación de mi historia y mi lenguaje ${ }^{62}$.

Así pues el Lope de Aguirre que estamos analizando es el primero de los personajes posseanos que se crea con un patrón genuinamente americano, autóctono. En esta reorientación hacia un universo más enraizado en lo amerindio creemos ver una inclinación especial hacia lo argentino. Daimón supone la inauguración de una nueva óptica narrativa y para configurarla se parte de modelos fundacionales básicos de la argentinidad literaria. De hecho, perviven amalgamadas en Aguirre dos figuras prototípicas de este ámbito; nos referimos a Facundo (1845) y Martín Fierro (1872), los dos últimos interlocutores que cerrarán este juego intertextual. Ambas obras, fruto del Romanticismo literario argentino, aparecen más o menos parodiadas en Dai$m o ́ n{ }^{63}$, pero su presencia va más allá de la mera interpolación libresca para configurar rasgos elementales de la caracterización del tirano. Para muchos Facundo y el gaucho Fierro son personajes antagónicos, pero ambos parten de un mismo principio: el rechazo de cualquier tipo de autoridad. El problema es que esta negación tiene razones diferentes: Facundo abomina de toda imposición porque pretende fundar su propio sistema de poder, donde él mismo represente la ley; Martín Fierro encarna un anhelo de libertad sin ambages, que no sea coartado por nada ni nadie. Nuestro Aguirre toma elementos de los dos, así los aúna, los enfrenta y, finalmente, los reconcilia en este proceso dialéctico que es toda la novela.

Sarmiento escribe su obra como ataque personal contra el sistema político de Rosas, apoyado en su autocracia por caudillos semisalvajes como Facundo Quiroga, representante de la bárbara esencia de América que era necesario combatir con el principio civilizador. «El tigre de los llanos» es caracterizado con un titanismo atroz, hasta el punto de dibujar por primera vez el prototipo literario que más tarde protagonizará la novela de dictador, de prolífico cultivo en Hispanoamérica ${ }^{64}$. Hay puntos de concomitancia entre Facundo y Aguirre, como su rebeldía absoluta ya que aquél, como éste, «no podía sufrir el yugo de la disciplina, el orden del cuartel ni la demora de los ascensos. Se sentía llamado a mandar, a surgir de un golpe, a crearse él solo» ${ }^{65}$. Ambos albergan un "odio invencible, instintivo, contra las leyes que lo han perseguido» ${ }^{66} \mathrm{y}$ son fuerzas de la naturaleza (tal vez daimones) que evidencian unos «instintos hostiles a la civilización europea y a toda organización regular» y un rechazo tanto «a la monarquía como a la república, porque ambas venían de la ciudad, y traían aparejado un orden y la consagración de la autoridad ${ }^{67}$. No sólo hay similitudes en la caracterización de los protagonistas, sino también en la manera de presentarlos para hacer trascender desde ellos interpretaciones más abarcadoras y coetáneas; si Sarmiento habla de Facundo para mostrarnos el origen, la simiente, de la maldad engendrada por Rosas, Posse nos plantea un Aguirre precursor de la fuerza tiránica de las dictaduras. Rosas y Carrión habrían construido desde la ira desorganizada e individualista de sus predecesores un sistema perfecto de opresión y dominio ${ }^{68}$. Y también podemos establecer un paralelismo entre ambos textos al referirnos al ejercicio de nigromancia, de «invocación», del que parten ambos autores para rastrear en los protagonistas del pasado las explicaciones a un presente convulso. Sarmiento invoca en su introducción a Facundo para lograr entenderlo tanto a él como a su prédica, que aún pervive:

¡Sombra terrible de Facundo voy a evocarte, para que sacudiendo el ensangrentado polvo que cubre tus cenizas, te levantes a explicarnos la vida secreta y las convulsiones internas que desgarran las entrañas de un noble pueblo! Tú posees el secreto: revélanoslo. Diez años aún después de tu trágica muerte, el hombre de las ciudades y el gaucho de los llanos argentinos, al tomar diversos senderos en el desierto, decían: «iNo!, jno ha muerto! (...)» Cierto! Facundo no ha muerto; está vivo en las tradiciones populares, en la política y revoluciones argentinas, en Rosas, su heredero, su complemento ${ }^{69}$.

Posse también «invoca» a un personaje de ultratumba, y lo hace traer de nuevo convencido de que su herencia pervive y que «esa impronta anárquica y salvaje» que él representaba «es la que permaneció en América»70. Facundo se nos presenta como el «gaucho malo», alguien que «no podía abandonar su
62

Abel Posse en La Semana de Autor, op. cit., p. 40.

63

Marina Kaplan cree ver en Daimón una parodia en todos los sentidos, que afectaría literariamente a los motivos y valores propios del Romanticismo hispanoamericano. Véase Marina E. Kaplan, "Daimón o la ausencia del padre», en Anna Houskova y Martín Procházka (eds.), Utopías del Nuevo Mundo, Praga, Academia Checa/Charles University, 1993, pp. 272-286.

64

Jaime Alazraki comenta en su artículo «Facundo, de Sarmiento, y la novela hispanoamericana del dictador» (Casa de las Américas, XXX, 180, 1990, pp. 14-28) que "constituye la expresión más temprana del género» (p. 15) y que "Sarmiento crea con Facundo un tipo, el embrión de un personaje literario que alcanza su adultez en la novela hispanoamericana contemporánea del dictador» (p. 22).

65

Domingo Faustino Sarmiento, Facundo, Madrid, Cátedra, 2005, p. 136

66

Ibid., p. 141.

67

Ibid., p. 110.

68

De hecho en Facundo se dice de Rosas: "su talento ha consistido en plagiar a sus antecesores, y hacer de los instintos brutales de las masas ignorantes un sistema meditado y coordinado fríamente», op. cit., p. 111

69

Ibid., pp. 37-38.

70

Abel Posse en La Semana de Autor, op. cit., p. 77.

La figura de Lope de Aguirre en Abel Posse: La fragua del personaje MERCEDES CANO PÉREZ 
71

Sarmiento, Facundo, op, cit., p. 198.

72

Daimón, p. 249.

73

José Hernández, Martín Fierro, Barcelona, Editorial Juventud, 1995, p. 76.

74

Ibid., p. 113.

75

Ibid., pp. 113-114.

76

Daimón, p. 74.

77

Historiadores como Eliseo Reclús y Arístides Rojas ya se hicieron eco de estos elementos míticos presentes en la voz del pueblo.

78

Arturo Uslar Pietri, Cuentos completos, Madrid, Páginas de Espuma, 2006, pp. 164-169.

79

Daimón, p. 275. misión» ${ }^{71}$ como les sucede a todos los daimones, incluido el de Aguirre, que pese al empeño no logra salvarse y escapar de lo que es en sí un ejercicio de determinismo histórico impecable. Lope se cruza con Facundo en la novela cuando ambos están en el congreso de Chachapoyas que reúne a todos los apartados por el progreso civilizador; allí lo ve realizando eternamente su último viaje, en «un fúnebre galerón de seis caballos conducidos por gauchos degollados» $\mathrm{y}$ «exhibiendo el orgullo de la muerte» ${ }^{72}$.

José Hernández, en la primera parte de Martín Fierro nos muestra toda la poética del gaucho bueno, el hombre que vive en un entorno idílico y natural hasta que hace su funesta aparición la autoridad. Tras perder familia y hacienda sólo le queda la ira y aunque jura «ser más malo que una fiera» ${ }^{73}$ no busca la rebelión sino una huida personal hacia la libertad, la posibilidad de hallar un camino propio y sin imposiciones. Hay en él todo un afán escapista que culmina cuando, junto con su amigo Cruz, deciden dejar la civilización y cruzar la frontera con los «bárbaros», ya que «hasta los indios no alcanza/ la facultá del Gobierno» ${ }^{74}$. Los dos personajes, víctimas del desencanto, buscan la salvación al final de esa primera parte de sus aventuras en el ámbito de lo no-histórico, de lo que está fuera del cómputo humano que es el terreno amoral e inextricable de las tribus primitivas e indómitas. En la segunda parte de la obra, $L a$ vuelta de Martín Fierro (1879), el héroe vuelve desengañado de su incursión en lo bárbaro y decide reintegrarse en la sociedad y aceptar de nuevo sus reglas.

En el primer bloque de Daimón, titulado «La epopeya del guerrero», Aguirre sufre varios golpes emocionales que le hacen también querer salir de su rol histórico y del mundo cada vez más inhabitable de lo civilizado. Toda la segunda parte de la novela encarna este propósito de huida, de ahí que su significativo título sea «La vida personal». En esta fase el tirano abandona a sus marañones y busca soluciones individuales a su recién estrenado existencialismo místico, pero el amor tampoco consigue salvarlo y por ello al final decide volver de nuevo a la historia: el viaje de
Aguirre es, como el de Fierro, de ida y vuelta. Hay en la obra de Hernández una presencia inminente del peregrinaje, del vagabundeo. Como dice el propio personaje: "yo ruedo sobre la tierra/ arrastrao por mi destino» ${ }^{75}$. El espíritu del gaucho presupone lo errante de su condición, característica ésta de su falta de ataduras providencial. Este rasgo profundamente dinámico lo vemos también en Aguirre, incapaz de asentarse en un lugar mucho tiempo porque "parecía vivir sin paz, como amenazado por un fuego que siempre ardiese a sus espaldas» ${ }^{76}$.

\section{APUNTE FINAL: EL ÚLTIMO FUEGO}

Aguirre es, como Martín Fierro, un peregrino. Así se definió él mismo y así lo calificó más tarde Uslar Pietri en el célebre ensayo que citábamos al principio y al que volvemos para concluir esta reflexión, este mapa espiritual del protagonista de Daimón. El autor venezolano destacaba allí un rasgo que engloba definitivamente al personaje: la persistencia de Aguirre, su leyenda. En el fervor popular se gestó la fábula, la profecía de fuegos fatuos y luces azuladas que representaban en las noches venezolanas el alma errante e insatisfecha del tirano ${ }^{77}$. Uslar Pietri (autor a su vez de una de las más destacadas novelas sobre el personaje, El camino de El Dorado) no sólo describió este aspecto mítico en el mencionado ensayo sino que le dio cuerpo literario en su asombroso relato «El fuego fatuo» ${ }^{78}$. Posse hace lo propio en la novela, reflejando esta permanencia legendaria pero con un sentido histórico trascendente; Aguirre queda reducido a su leyenda viva, es sólo una presencia fantasmal pero amenazante, eternamente presente y expectante. Por ello, la leyenda popular de Lope de Aguirre recreada en el cuento de Uslar se manifiesta en Daimón como una peligrosa invocación para supersticiosos, un reducto de lo terrible, un recuerdo antiguo o, como se afirma en la novela:

...casi sólo una brisa, un fuego fatuo de las lagunas que obliga a las viejas pampeanas a santiguarse y rezar tres avemarías. Viento en el viento, agua en el agua, polvo en el polvo ${ }^{79}$. 